Contacts

Publisher: Ben Crowe

Editor: Paul Smaglik

Marketing Manager: David Bowen

European Head Office,

London

The Macmillan Building

4 Crinan Street

London N1 9XW, UK

Tel +44 (0) 2078434961

Fax +44 (0) 2078434996

e-mail: naturejobs@nature.con

Naturejobs Sales Director

Nevin Bayoumi (4978)

UK/ RoW/ Ireland:

Matt Powell (4953)

Andy Douglas (4975)

Frank Phelan (4944)

Scandinavia/ Spain/ Portuga:

Evelina Rubio Håkansson (4973)

Natureevents: Sille Opstrup (4994)

France/ Switzerland:

Amelie Pequignot (4974)

Production Manager: Billie Franklin

To send materials use London

address above.

Tel +44 (0) 2078434814

Fax +44 (0) 2078434996

e-mail: naturejobs@nature.com

Naturejobs web development

Tom Hancock

Naturejobs online production:

Stefan Hales

European Satellite Office

Germany/ Austria/ Italy/

The Netherlands/ Belgium

Patrick Phelan, Odo Wulffen

$\mathrm{Tel}+498954905711 /-2$

$\mathrm{Fax}+498954905720$

e-mail: p.phelan@nature.com o.wulffen@nature.com

US Head Office, New York

345 Park Avenue South,

10th Floor, New York, NY 10010-1707

Tel +1 8009897718

Fax +18009897103

e-mail: naturejobs@natureny.com

US Sales Manager: Peter Bless

Japan Head Office, Tokyo

MG Ichigaya Building (5F),

19-1 Haraikatamachi,

Shinjuku-ku,

Tokyo 162-0841

Tel +81332678751

Fax +81332678746

Asia-Pacific Sales Director:

Rinoko Asami

e-mail: rasami@naturejpn.com

\title{
naturejobs
}

\section{Out of fashion}

D avid Bowie once described fashion in an eponymously named song as full of "tension and fear". He was describing clothing, music and dancing, but he might as well have been singing about science.

Most scientists would scoff at such a suggestion, saying that they have no interest in keeping up with the cool kids at the bench next door. This may be true of superficial trappings - although some do have a need to sport the latest flat-screen display or highthroughput technology. But the real trend-setting runs a little deeper - it's the need to keep up with the pack in research topics. And pressure from external forces to make a researcher's science more relevant to society only exacerbates the issue.

It may seem like the best approach, but following trends can be detrimental to your career. A recent article in EMBO Reports (K. Weigmann EMBO Rep. 5, 1028-1031; 2004) presents a few case studies. After a Nobel prize and the scare over mad-cow disease, prions became 'flavour of the month' — which was good news for the few scientists already working in the field. But the huge boost in publicity prompted many others to jump on the bandwagon — and then the funds dried up.

Even if money had remained available, the hype would have attracted more competition, so ultimately everyone would have got less. Even in well-funded fields, it can be dangerous to jump on someone else's train - you might get scooped. But there is a solution. Ask a novel question and either invent a new technique or use the latest methods to answer it, says Bruce Alberts, president of the US National Academy of Sciences (see Nature 431, 1041; 2004).

It's much more satisfying to start a trend than follow one. And doing so means you won't end up a fashion victim.

\section{Paul Smaglik}

Naturejobs editor

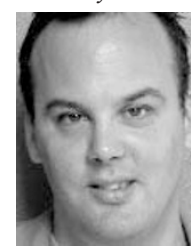

\section{Contents}

\section{CAREERS \& RECRUITMENT}

Biomedical engineering comes of age

\section{WWW.NATUREJOBS.COM}

Career centre

Information on the scientific job market
FOCUS

SPOTLIGHT

RECRUITMENT

ANNOUNCEMENTS 